\title{
GABA RECEPTORS AND PAIN REGULATION
}

\author{
VALERIO MAGNAGHI, MARCELLA MOTTA (*)
}

Nota presentata dal m.e. Marcella Motta

(Adunanza del 20 dicembre 2012)

SuNTO. - Il dolore è una risposta dell'organismo ad un insulto, esterno o interno. La sua funzione è quella di avvertire e proteggere l'organismo da ulteriori danni. L'Associazione Internazionale per lo Studio del Dolore ha definito il dolore come "esperienza sensoriale o emozionale spiacevole, associata ad un potenziale o reale danno tissutale o descritto come tale". Il dolore neuropatico è un tipo di dolore cronico che origina direttamente da un danno al sistema nervoso stesso, centrale o periferico. E' un tipo di dolore a lungo termine, con alta incidenza e di difficile trattamento farmacologico. I meccanismi fisiopatologici alla base del dolore cronico hanno identificato i neuroni sensoriali afferenti come il bersaglio primario per la terapia. Tuttavia, anche le cellule gliali centrali o periferiche (ad esempio le cellule di Schwann) sembrano essere fondamentali per il controllo del dolore. I circuiti nervosi, che coinvolgono l'acido $\gamma$-aminobutirrico $(G A B A)$ e i suoi recettori GABA-B, sono stati a lungo considerati in studi preclinici di dolore acuto e cronico. I recettori GABA-B coinvolti nelle vie del dolore sono recettori sopraspinali e spinali, presinaptici e postsinaptici. I recettori GABA-B sono presenti anche nei gangli dorsali spinali e negli assoni periferici. Di recente si è dimostrato che i recettori GABA-A e GABA-B sono funzionalmente attivi anche sulle cellule di Schwann. L'attivazione dei recettori GABA-A controlla la sintesi di GABA, attivando un meccanismo autocrino che regola la mielinizzazione periferica operata dalle cellule di Schwann. L'attivazione dei recettori GABA-B, invece, induce meccanismi autonomi e non-autonomi delle cellule di Schwann. I recettori GABA-B controllano la struttura e l'espressione delle proteine mieliniche. Inoltre, i recettori GABA-B inducono modificazioni indirette del compartimento neuronale periferico, controllando il numero di fibre

(*) Dipartimento di Scienze Farmacologiche e Biomolecolari, Università degli Studi di Milano, Via G. Balzaretti 9, 20133 Milano, Italy.

E-mail: valerio.magnaghi@unimi.it 
amieliniche, deputate alla trasmissione nocicettiva, quindi partecipando al dolore periferico. Queste osservazioni sono importanti per lo sviluppo della futura farmacoterapia del dolore, che dovrebbe tenere in considerazione il coinvolgimento delle cellule gliali e i meccanismi neuropatologici alla base del dolore cronico.

$* * *$

ABSTRACT. - Pain is an adaptive sensation that normally appears as a warning, activated in response to a damage of the organism. Pain serves to protect the organism to further tissue injuries. The International Association for the Study of Pain (IASP) defined pain as "an unpleasant sensory and emotional experience associated with actual or potential tissue damage, or described in terms of such damage" (see definition on the IASP homepage at www.iasp-pain.org). Pain can be generally divided into two categories, acute and chronic pain: acute pain is properly a sudden warning pain which signals that something is wrong in the body. If the cause is not removed acute pain may develop in chronic pain, which is persistent and debilitating.

When a damage or a dysfunction affects directly the central or the peripheral nervous system, so that the pain becomes the pathology, it is termed neuropathic pain. It can be described as burning, tingling, shooting, stabbing, or shocking. Injury to the brain, brain tumors, diabetic neuropathy as well as herpes zoster are among the pathologies that may cause this type of pain [1]. Neuropathic pain is often underdiagnosed and undertreated, and it is associated with suffering, disability, impaired quality of life, and increased cost. Neuropathic pain is a long-term process that results difficult to treat.

The increasing knowledge of the mechanisms of pain identified the primary afferent neurons as an important target for the development of novel analgesics. However, neuropathic pain is an heterogeneous process, in terms of etiological factors, molecular mechanisms, but also cells involvement [2]. The central (i.e., astrocytes, oligodendrocytes) and peripheral glial cells (i.e., Schwann cells) are fundamental for the regulation of neuronal activity and also for the control of the nociceptive transmission.

$\gamma$-aminobutiric acid (GABA) is generally considered the main inhibitory transmitter in the nervous system, being involved in the processing of nociceptive information. These effects are mediated through activation of ionotropic (i.e. GABA-A) and metabotropic (i.e. GABAB) receptors. In particular, the importance of GABA-B receptors in nociceptive processing was well documented in the early 90's, in a series of preclinical studies in which the GABA-B specific agonist baclofen 
proved to be antinociceptive in models of acute and chronic pain $[3,4]$. These effects are likely mediated by spinal and supraspinal GABA-B receptors. The supraspinal effects appear to reflect depression of ascending adrenergic and dopaminergic inputs to the brainstem, and facilitation of descending nor-adrenergic input to the spinal cord dorsal horn [5]. At spinal cord level, the baclofen-induced analgesic effect is attributed to the activation of presynaptic GABA-B receptors, localized on the terminals of peptidergic primary afferents fibers, which determine the suppression of transmitter release [6]. GABA-B receptors are also involved in the inhibitory effects of other co-neurotransmitters on glutamatergic synaptic transmission and pain [7]. However, postsynaptic mechanisms are involved. Indeed, the decrease of dorsal horn neuron excitability and the regulation of intrinsic neuronal properties $[8,9]$ suggest an additional postsynaptic GABA-B mechanism on pain. GABA-B receptors exert a basal inhibition that is induced by a tonic excitatory control through the group I metabotropic glutamate receptors (mGluR), thus resulting in a dynamic balance of inhibitory and excitatory inputs on the dorsal horn neurons [9]. Both GABA-B receptors and group I mGluRs modulate inwardly rectifying potassium (Kir) channels, L-type and N-type voltage-gated calcium channels $[10,11]$. The contribution of GABA-B receptors to the nociceptive processing was further explored with GABA-B1 knock-out mice [12]. Acute mechanical and thermal thresholds to painful stimuli were reduced in knock-out animals. Thus, tonic GABA-B receptor activation appears to contribute to the establishment of a nociceptive threshold. However, the use of baclofen in clinical practice has been limited due to a rapid tolerance and the possible desensitization of GABA-B receptors.

In the mid-70's the studies on the presence of GABA and its receptors outside the central nervous system were performed. Indeed, the accumulation of ${ }^{3} \mathrm{H}-\mathrm{GABA}$ was shown in Schwann cells of the taste buds of the amphibian necturus maculosus [13]. At the peripheral nervous system (PNS) level, the presence of GABA-B receptors has been then demonstrated in the rat dorsal root ganglion (DRG), in peripheral axons, in autonomic nerve terminals and in pig nodose ganglion cells [14-19]. Recently, we showed that Schwann cells express different active isoforms of GABA-B receptors, such as -1a, $1 b,-1 c$, and $-2[20,21]$. Exposure of Schwann cells to the specific GABA-B agonist baclofen, instead, decreases the cell proliferation and the percentage of Schwann-BrdU immunopositive cells. Baclofen 
also decreases the levels of the specific P0 and PMP22 peripheral myelin proteins, suggesting a GABA-B mediated control of peripheral myelination [21]. Interestingly, the presence of possible autocrine GABA-B mediated mechanisms in the PNS has been suggested by the capability of Schwann cells to synthesize GABA. It may activate autocrinally either the GABA-B or the GABA-A receptors, regulating the Schwann cell development [22]. Therefore, the PNS is a potential target for GABA's action, suggesting that GABA-A and GABA-B receptors cross-interact in a complex mechanism influencing the Schwann cell biology [23].

Given the thermal hyperalgesia and the lack of allodynic behavior observed in GABA-B1 knock-out mice, this type of animals has been used to assess the peripheral contribution of GABA-B receptors to the nociceptive processing [24]. Indeed, the morphologic and biomolecular analysis of GABA-B1 knock-out mice further evidences the role of this receptor in the PNS. GABA-B1-deficient mice exhibited morphological and molecular changes in peripheral myelin, including an increase in the number of irregular fibers and in the expression levels of PMP22 and P0 [24]. In particular, these mice presented a high number of small myelinated fibers and small neurons of the lumbar DRG [24], suggesting a role for GABA-B in the control of the peripheral nociceptive fibers. Although, GABA-B receptors may have activational effect in PNS, the possibility that the sensory nerve fiber dysmyelination contributes to the nociceptive phenotype is plausible. A peripheral co-regulation between GABA-A and GABA-B receptors in the control of Schwann cell physiology may contribute to add more complexity to these mechanisms [25]. GABA-A receptors, in fact, are present in Schwann cells, they participate in the control of myelin protein expression and they show opposite effects to GABA-B activation [25]. A similar cross-interaction between GABA-A and GABA-B receptors may explain the decrease in antinociceptive potency of baclofen in those mice lacking the GABA-A 3 subunit [26]. In a model of diabetic neuropathy, bearing peripheral demyelination and neuropathic pain, the increased glutamatergic input from primary afferents to dorsal horn neurons is the result of a reduction in presynaptic GABA-B receptors [27]. However, in the PNS of GABA-B1 knock-out mice not only the peripheral myelin but also the neuronal compartment was modified [24]. Electron microscopy analysis of the lumbar DRG, where the soma of the sensory neurons that synapse the lamina I-IV of the spinal dorsal 
horn are located, showed an increase in small neurons [24]. The small sensory neurons of the DRG with thin myelinated axons usually origin the A $\delta$ fibers [28]. The altered morphological findings in the PNS of GABA-B1 knock-out mice, such as the high number of myelinated

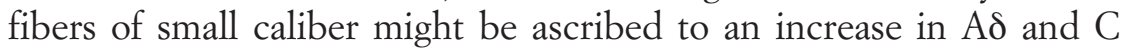
fibers. Moreover, the neuropathologic analysis of the skin, revealed that the number of intraepidermal unmyelinated sensory fibers, mostly representing $\mathrm{C}$ fibers, is normal in GABA B1 knock-out mice. In agreement, the immunolabeling of the peripheral nerves for specific neuropeptides (e.g. CGRP) or neurofilaments (i.e. NF200) confirmed that likely A $\delta$-sensory fibers are increased in the GABA-B1 knock-out mice. However, some extrasynaptic roles for GABA-B receptors in nociception have been also demonstrated at the spinal level. Post synaptic effects of GABA-B1b-containing receptors have been demonstrated in somatosensory neurons, whereas GABA-B2/GABA-B1b dimers specifically induce postsynaptic, long-lasting inhibition of dendritic $\mathrm{Ca}^{2+}$ spikes [29]. The involvement of calcium channels in GABA-B-mediated control of neuronal activity has been documented in the spinal cord.

In conclusion, chronic and neuropathic pains are still far from the identification of clinic reliable therapies. The involvement of glial cells in the neuropathologic and molecular mechanisms of pain should be taken in consideration to improve the future pharmacotherapy of neuropathic pain. We showed that the GABAergic system (GABA and its GABA-A and GABA.B receptors) is functionally present in Schwann cells. GABA-A receptors, via activation of the PK-A and PK-C signaling pathways, control the GABA synthesis in Schwann cells and supply an autocrine loop that, in turn, regulates peripheral myelination. GABA-B receptors induce either Schwann cell autonomous or nonautonomous mechanisms. GABA-B receptors control myelin structure, myelin protein expression and Schwann cell structure. Moreover, GABA-B receptors induce Schwann cell mediated changes in the neuronal compartment, controlling the number of unmyelinated fibers, thus participating actively to the peripheral nociception. Future pharmacotherapy of neuropathic pain should necessarily take in account these issues. 


\section{BIBLIOGRAPHY}

[1] TREeDE R.D. et al. (2008), Neuropathic pain: redefinition and a grading system for clinical and research purposes, Neurology 70, 1630-5.

[2] Yamanaka H. AND Noguchi K. (2012), Pathophysiology of neuropathic pain: molecular mechanisms underlying central sensitization in the dorsal born in neuropathic pain, Brain Nerve 64, 1255-65.

[3] Malcangio M. and Bowery N.G. (1995), Possible therapeutic application of $G A B A B$ receptor agonists and antagonists, Clin Neuropharmacol 18, 285-305.

[4] Patel S. et al. (2001), The effects of $G A B A(B)$ agonists and gabapentin on mechanical byperalgesia in models of neuropathic and inflammatory pain in the rat, Pain 90, 217-26.

[5] SAWYNOK J. (1984), GABAergic mechanisms in antinociception, Prog Neuropsychopharmacol Biol Psychiatry 8, 581-6.

[6] PRICE G.W. et al. (1984), Are baclofen-sensitive GABAB receptors present on primary afferent terminals of the spinal cord?, Nature 307, 71-4.

[7] SUZUKI T. et al. (2005), Effect of a selective GABA(B) receptor agonist baclofen on the mu-opioid receptor agonist-induced antinociceptive, emetic and rewarding effects, Neuropharmacology 49, 1121-31.

[8] Kangrga I., Jiang M.C. And Randic M. (1991), Actions of (-)-baclofen on rat dorsal horn neurons, Brain Res 562, 265-75.

[9] DERJEAN D. et al. (2003), Dynamic balance of metabotropic inputs causes dorsal horn neurons to switch functional states, Nat Neurosci 6, 274-81.

[10] Voisin D.L. AND Nagy F. (2001), Sustained L-type calcium currents in dissociated deep dorsal horn neurons of the rat: characteristics and modulation, Neuroscience 102, 461-72.

[11] TOMBLER E. et al. (2006), G protein-induced trafficking of voltage-dependent calcium channels, J Biol Chem 281, 1827-39.

[12] SCHULER V. et al. (2001), Epilepsy, hyperalgesia, impaired memory, and loss of preand postsynaptic $G A B A(B)$ responses in mice lacking $G A B A(B(1))$, Neuron 31, 47-58.

[13] NAGAI T. et al. (1998), Uptake and release of neurotransmitter candidates, [3H]serotonin, [3H]glutamate, and [3H]gamma-aminobutyric acid, in taste buds of the mudpuppy, Necturus maculosus, J Comp Neurol 392, 199-208.

[14] BOWERY N.G. et al. (1981), Bicuculline-insensitive GABA receptors on peripheral autonomic nerve terminals, Eur J Pharmacol 71, 53-70.

[15] Desarmenien M. et al. (1984), Coexistence of GABAA and GABAB receptors on $A$ delta and $C$ primary afferent, Br J Pharmacol 81, 327-33.

[16] LISKE S. AND MORRIS M.E. (1994), Extrasynaptic effects of GABA (gammaaminobutyric acid) agonists on myelinated axons of peripheral nerve. Can J Physiol Pharmacol 72, 368-74. 
[17] Sun B.B. AND CHIU S.Y. (1999), N-type calcium channels and their regulation by GABAB receptors in axons of neonatal rat optic nerve, J Neurosci 19, 5185-94.

[18] TOWERS S. et al.(2000), GABAB receptor protein and $m R N A$ distribution in rat spinal cord and dorsal root gangli, Eur J Neurosci 12, 3201-10.

[19] ZagorodNyUK V.P. et al. (2002), Functional GABAB receptors are present in guinea pig nodose ganglion cell bodies but not in peripheral mechanosensitive endings, Auton Neurosci 102, 20-9.

[20] Magnaghi V. et al. (2006), GABA receptor-mediated effects in the peripheral nervous system: A cross-interaction with neuroactive steroids, J Mol Neurosci $\mathbf{2 8}$, 89-102.

[21] MAGNAGHI V. et al. (2004), GABAB receptors in Schwann cells influence proliferation and myelin protein expression, Eur J Neurosci 19, 2641-9.

[22] Magnaghi V. et al. (2010), GABA synthesis in Schwann cells is induced by the neuroactive steroid allopregnanolone, J Neurochem 112, 980-90.

[23] Magnaghi V., Procacci P. and Tata A.M. (2009), Novel pharmacological approaches to schwann cells as neuroprotective agents for peripheral nerve regeneratio, Int Rev Neurobiol 87, 295-315.

[24] Magnaghi V. et al. (2008), Altered peripheral myelination in mice lacking GABAB receptor, Mol. Cell. Neurosci. 37, 599-609.

[25] Magnaghi V. (2007), GABA and neuroactive steroid interactions in glia: new roles for old players?, Curr Neuropharmacol 5, 47-64.

[26] UGARTE S.D. et al. (2000), Sensory thresholds and the antinociceptive effects of $G A B A$ receptor agonists in mice lacking the beta3 subunit of the $G A B A(A)$ receptor, Neuroscience 95, 795-806.

[27] WANG X.L. et al. (2007), Altered synaptic input and GABAB receptor function in spinal superficial dorsal born neurons in rats with diabetic neuropath, J Physiol 579, 849-61.

[28] RuSCHEWEYH R. et al. (2007), Modification of classical neurochemical markers in identified primary afferent neurons with Abeta-, Adelta-, and C-fibers after chronic constriction injury in mice, J Comp Neurol 502, 325-36.

[29] PereZ-GARCI E. et al. (2006), The GABAB1b isoform mediates long-lasting inhibition of dendritic Ca2+ spikes in layer 5 somatosensory pyramidal neurons, Neuron 50, 603-16. 
